\title{
The Manifestation of the Qur'an in the Ethical Narratives of Imam Muhammad Bāqir (AS)
}

\author{
Asst. Prof. Dr. Tahereh Sadat Tabataba'i Amin, \\ University of Quranic Sciences, and Knowledge, Tehran \\ tabatabaei.amin@gmail.com
}

\author{
Dr. Rafid Sabbar Abbas, \\ Electrical Engineering, Faculty of Engineering, Kufa University, \\ rafids.abbas@uokufa.edu.iq
}

Received: $165 / 16 / 7 / 2020$

Accepted: 180/16/8/2020

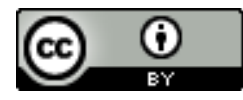

This work is licensed under a Creative Commons Attribution 4.0 International License Abstract

The infallible imams of Shi'a have a special interest in human values and have repeatedly advised people to adhere to moral virtues. In this study, a collection of ethical narratives of the fifth Imam of Shi'a, Imam Muhammad Bāqir (AS), has been presented, in which verse or verses of the Qur'an have been manifested. These narratives are then analyzed. The verses of the Qur'an have been expressed in the words of Imam Bāqir (AS) in various ways, including: adduce, citation, allusion, adaptation, or expression of instance. This research pursues several goals: First: Understanding how Imam Bāqir (AS) has used the Qur'an in his speech. Second: a detailed understanding of the subject of these narratives and the interpretation of the verses in which they are mentioned; Third: The relationship between the above verses and the narrative text.

In the 14 hadiths of Imam Bāqir (AS), about 30 verses of the Qur'an have been manifested which have yielded important results from their analysis. Including: All the Imams in general and Imam Bāqir (AS) in particular, pay great attention to the Quran. And teach people to seek every true idea and belief from the verses of the Qur'an, to question the master and have a scientific debate and controversy, to bring their evidence from the Qur'an as the most important scientific and religious source, and to ignore the word that has no Qur'anic reason, and not to suffice the appearance of Qur'an and pay attention to its hidden meaning. Some of the ethical virtues that Imam Muhammad Bāqir (AS) has explained include: flexibility in accepting the right, believers' dignity, public relations, rationality in public relations, avoiding the vain and futile word, avoiding many questions, avoiding nonsense and slander toward people, avoiding illicit relationships and short-change.

Keywords: Imam Mohammad Bāqīr (AS), Ethics, Manifestation of Qur'anic Verses, Interpretative Narratives. 


\section{Introduction}

Hadith is the second source of Islamic law and many of religious teachings are rooted in it. Shi'a Imams consider the accuracy in understanding the hadith better than memorizing it without any attention (Sheikh Sadūq, 1403, p. 1-2), and have encouraged the Shi'ite to understand the hadith and act upon its content. The Imams (AS), in their hadiths, have emphasized greatly on ethical issues. This article presents narratives of the fifth Imam of Shi'a, Imam Muhammad Bāqir (AS), who has explained the moral virtues by adopting the Qur'an and its verses. Ethical virtues such as: flexibility in the acceptance of the right, the dignity of believers, public relationship, rationality in public relations, avoiding the vain word, avoiding too many questions, avoiding nonsense and slander toward people, avoiding illicit relationships, etc.

In terms of structure and content, the Qur'an is a masterpiece whose verses have had a significant and unconscious impact on Muslim literary and poets and have led to purposeful and extraordinary artistic works and creations. (Ayazi, 1381, p. 47) One of the ways in which a verse or part of a verse can be applied to a literary text is "adaptation".

The infallible Imams have also adorned their sayings, sermons, prayers and narratives with the verses of the Qur'an and sometimes adapted from the verses of the Qur'an. In the narratives of the Prophet (PBUH) and Ahl al-Bayt (AS), the verses of the Qur'an have been manifested in various ways. Sometimes they recite a verse to interpret it, sometimes they use the verse as a reason or document for their word (citation), sometimes they mention it as an evidence for their word (adduce) and sometimes they refer to the verses of the Qur'an as allegory and allusion.

In this article, it has been attempted to collect ethical narratives from Imam Bāqir (AS) in which verse or verses of the Qur'an have been manifested. To compile the narratives, the book "Tafsir Noor al-Thaqalayn" has been used. The book was chosen because it is comprehensive in this field and responds to the subject in question. The hadiths were first collected from the entire five-volume book of Tafsir Noor al-Thaqalayn. Then the repetitive and weak narratives were eliminated. The hadiths of Tafsir Noor al-Thaqalayn were sometimes without document, and sometimes the text of the hadith is incomplete, so, the document and the text of narrative was supplemented by searching for original sources, such as the book "Kafi".

\section{Types of Qur'anic manifestation in the hadiths}

The verses of the Qur'an appear in several ways in the narratives of the Imams. Sometimes the Imam cites the verses of the Qur'an in order to express his words, sometimes he brings the Qur'anic verses as a witness for his speech, that is, he adduces, sometimes he adapts the verses, and sometimes in his speech he refers to the verses of the Qur'an i.e. allusion. The concept of citation, adduce, adaptation and allusion is now presented. 


\section{Adduce}

One of the manifestations of the verses of the Qur'an in the narratives of the Imams (AS) is adduce. The adduce was taken from "martyr" and is synonym with "testimony" Adduce literally means witnessing someone for something. (Ibn Manz ūr, 1414, vol. 3, p. 240) In this text, adduce means bringing the verse as a witness and confirming the speech.

\section{Adaptation}

Al-Qabas: A flame of fire that is taken from a great fire (Farāhīdī, 1409, v. 5, p. 86; Ibn Duraid, nd, v. 1, p. 338) it is said: I have taken fire from someone and I have taken a science from him and I will give some to you ${ }^{1}$ (Ibn Duraid, nd, vol. 1, p. 339). Adaptation in the rhetoric term: means that the speaker brings up a verse, a hadith or a poem in his speech, without mentioning its source so as to make it clear that it is intended for adaptation (Taftazani, 1411, p. 308).

After the revelation of the Qur'an, the adaptation from Qur'an was considered an honor for the poet and to adorn his work. (Abbaszadeh, 1389, p. 40) From the early days of Islam, adaptation was widespread and has been considered as one of the merits of science of Rhetoric (Ma'refat, 1423, p. 238.) When the religion of Islam expanded, no lecturer or poet had something to say against the Qur'an. (Tha'labī, 1386, p. 35)

\section{Allusion}

Allusion in the word means looking with the corner of eye. (Dad, 1371, p. 86). In the rhetoric term, allusion is to refer to a story or poem without quoting it (Taftazani, 1411, p. 312). In this article, allusion means referring to a corner of the Quranic verse without mentioning the full verse and without mentioning its source.

\section{Definition of Ethics}

\section{Ethics is defined as:}

Ethics is the queen traits of soul and the spiritual state that makes ugly or beautiful works be easily driven from a soul belonging to a particular ethic. (Jawādī Âmulī, 1377, v. 10, p. 73). So if a man performs a good or bad and it becomes a habit for him, then one can say that his ethics is the same. Scientists regard the tendency for human and moral values to be innate and say:

Moral values are things that human nature accelerates toward them, and God has created the tendency toward these things in the soul of all people to reach them through voluntary actions. And it is by virtue of these tendencies that 'Dos' and 'Don'ts' emerge as a series of revelations in the soul (Motahhari, 1389, v. 2, p. 195). 


\section{The Manifestation of the Verses of the Qur'an in the Ethical Narratives of Imam Bāqir (AS)}

In this study, 14 ethical narratives of Imam Bāqir (AS) were studied, in which about 25 verses of the Qur'an were revealed. These narratives are in two categories. The first category has 9 narratives that refer to good traits. The second category has 5 narratives that refers to bad traits. Below we will examine these two categories.

\section{Manifestation of Qur'anic verses in the ethical narratives of Imam Bāqir (AS) and ordering good traits}

In these narratives, Imam Bāqir (AS) has mentioned 9 ethical issues of human values and good traits: In the following we have examined the manifestation of Qur'anic verses in these narratives.

\section{Flexibility in accepting the right}

Abi Basir quotes from Imam Ja'far Sadiq (AS): "The human heart is anxiously moving from its own place to the larynx until it achieves the truth then it will be quiet." Imam then clasped his fingers together and recited this verse:

(And whomsoever Allah Wills to guide, Expands his breast for Islam, and Whomsoever He Wills to be left in his Error, He makes his breast closed and narrow as if he is climbing up to the very sky. Thus Allah puts an Ignominious Chastisement on those who refuse to believe ${ }^{1}$ ) (AlAn $\square \bar{a} m / 125$ ) (Ayyashi, 1380, v. 1, p. 377; Huwayzī, 1415, v. 1, p. 766)

Here Imam Bāqir (AS) adduces the verse 125 of surah An $\square \bar{a} m$.

Allameh Tabataba'i says: The verse 125 of surah An $\square$ ām can be interpreted by verse 23 of Surah Az-Zumar: The heart-expansion is to have a divine light in the heart and this light guides the human and the heart-expansion is opposite to the heart-barbarity. The almighty God says:

(Allah has revealed (from time to time) the most beautiful Message in the form of a Book, consistent with itself, (yet) repeating (its teaching in various aspects): the skins of those who fear their Lord tremble thereat; then their skins and their hearts do soften to the remembrance of Allah. Such is the guidance of Allah. He guides there with whom He pleases, but such as Allah leaves to stray, can have none to guide. $\left.{ }^{2}\right)(\mathrm{Az}-\mathrm{Zumar} / 23)$

So the divine guidance is that it softens the heart toward the remembrance of God and the acceptance of the right. (Tabataba'i, 1417, v. 7, p. 342) 
This statement of Allameh is in line with the Prophet's (hadith) narrative that said: "The heart-expansion is a light that God sheds in the heart of the believer and expands his chest" (Ray Shahri, nd, V. 3, p. 2608).

The phrase (Whomsoever He wills to be left in his error, He makes his breast closed and narrow $^{1}$ ) (Al-An $\left.\square \bar{a} m / 125\right)$ means that in the breast which is covered by the rust of the idolatry, no light of faith can enter and no advice can be accepted. (T abarī, 1412, v. 8, p. 38) No good penetrates such a heart. (Suyūt î, 1404 , v. 3, p. 45)

The phrase (as if he is climbing up to the very $s k y^{2}$ ) means that when they invite him to Islam, he becomes so disgusted that he seems to be asked to do a difficult job or they have told him to go up in the sky (T abarsī, 1372, v. 4, p. 159). The scientific interpretation of this verse is (climbing up to the very $\mathrm{sky}^{3}$ ): It is difficult to breathe in the upper part of the sky scientifically, and the severe shortness of breath causes man to die so the almighty God has said: (A misguided man who refuses to accept the truth is like one who ascends the upper floors of heaven.)

It comes from the word of Imam Bāqir (AS) that the soul of every human being is searching the truth and the expression, "human heart is anxiously moving from his place to the throat when it has not found the truth ${ }^{4}$, apparently means the anxiety of the soul searching the truth. When we say ten times a day in our obligatory prayers (guide us to the straight path), is for the fact that God turns and surrenders our hearts to the truth.

\section{Attention to the will of God}

Imam Bāqir (AS), in the explanation of the following verse, said:

(We had already, beforehand, taken the covenant of Adam, but he forgot: and We found on his part no firm resolve) (T⿳亠㐅⿵冂卄 Hā/115)

When God told Adam (AS) to enter Paradise, told him: "O, Adam, don't approach this tree." Then Adam told his Lord: "How can I approach this tree, while You have forbidden me and my wife from it?" God told him: "Don't approach it means don't eat it." Adam and his wife said: "Ok, we don't approach it and don't eat it." But they didn't say "God Willing." So God left them to themselves. God has said his prophet in the holy Qur'an:

(And say not of anything: Lo! I shall do that tomorrow. ${ }^{5}$ ) (Kahf/23) 


\section{But say: (God Willing. $\left.{ }^{1}\right)$}

Because (may) God doesn't allow me do it, so I will not be able to do so. That's why the Almighty God says: (and remember thy Lord when thou forgettest ${ }^{2}$ ) (Kahf/24)

Namely say (if God wills ${ }^{3}$ ) whenever you wanted to do something.

"(Kulaynī, 1407, v. 7, p. 448; H.uwayzī, 1415, v. 3, p. 254)

Imam Bāqir (AS), in the interpretation of verse 115 of surah TT $\bar{a}$ Hā, adduces the verses $23-24$ of surah Kahf.

The word exception means to remove or separate something from something. (Ibn Manz ūr, 1414, v. 14, p. 124) is rooted from "than $\bar{a}^{-4}$ " which is used in something in which a number or repetition is validated (Rāghib Isfihānī, 1412, p. 82).

The Shi'a and Sunni exegetes generally define the exception as saying "God Willing" because someone who says: I will do this unless God wills; this (unless) is an exception and means that If God wills, He will detain me (T abarī, 1412, v. 29, p. 37; Tūsī, nd, v. 10, p. 79; Ṭabarsī, 1372, v. 10, p. 92; , Qurț ubī, 1363, v. 18, p. 241; Tha $\square$ ālibī, nd, v. 5, p. 468; Feyz Kashani, nd, v. 5, p. 211; Ibn Jawzī, 1422, v. 8, p. 71; Tabataba'i, 1417, v. 19, p. 274)

In this narrative, Imam Bāqir (AS) has stated an instance of the negative consequence of not saying "God Willing" (the lack of exception), which is the same forgetfulness and little determination of Prophet Adam in refraining from eating the fruit of that forbidden tree. So to say "God Willing" is to pay attention to God's will, which is above our desires.

\section{The Dignity and Salvation of the Believers}

Imam Bāqir (AS) states: "God has given the believer three attributes: dignity in the world, salvation in the hereafter, and awe in the hearts of the oppressors. Then he recited the verse 8 of surah Munāfiqūn: (Honor belongs to Allah and His Messenger, and to the Believers.) Then he cited the verses $1-11$ of surah Mu'minin to prove the dignity of the believers. (Ibn Babawayh, 1362, v. 1, p. 152)

Allameh Tabataba'i says:

Faith means accepting and believing in something, by believing in its tools. So, one who believes in God obeys the commands of God's prophets. That is why whenever the Qur'an 
reminds believers, brings faith with a righteous act. Although the believer sometimes disobeys some of the tools of faith due to bodily obstacles, he should not violate all of its tools (Tabataba'i, 1417, v. 15, p. 6).

Imam Bāqir (AS) recites verses 1-11 of surah Mu'minin after mentioning the good consequences of faith. These verses indicate that salvation is for believers who perform certain acts: Translation of verses 1-11 of surah Mu'minin:

(Successful indeed are the Believers, Those who humble themselves in their prayers; Who avoid vain talk; Who are active in given Zakat; Who guard their modesty. Except with those joined to them in the marriage bond, or (the captives) whom their right hands possess, for (in their case) they are free from blame. But those whose desires exceed those limits are transgressors. Those who faithfully observe their trusts and their covenants; and who (strictly) guard their prayers; these will be the heirs. Who will inherit Paradise: they will dwell therein (forever) ${ }^{1}$ ) (Mu'minin/11)

Success (Faläh) means victory and achieving the desire. And these are two kinds, whether it is a worldly success or a heavenly success. The worldly success is achieving the blessings that make the life of the world happy. These blessings are: survival, wealth and dignity. The heavenly success is also: immortal survival, and wealth without poverty and knowledge without ignorance.

\section{The Role of righteous deed in becoming heavenly}

Imam Bāqir (AS) said: Know it, Fự ayl; I swear to God that you are the only pilgrims of God and the Divine Mercy is just for you and your deeds are accepted and surely you are the instance of this verse: (If ye (but) eschew the most heinous of the things which ye are forbidden to do, We shall remit your evil deeds, and admit you to a Gate of great honor.) (An-Nisāa/31) O, Fud ayl, are you not pleased that you enter the Paradise by saying prayers, paying Zakat and avoiding (persecuting) the others with your tongue? (Kulaynī, 1407, v. 8, p. 288-289)

Imam Bāqir (AS) in this word has adduced the verse 31 of surah Nisā $\square$ and has quoted the verse as proof that you will surely become a heavenly person by observing a few things. Minor and Major Sins: There is a debate among scholars as to whether sins can be divided into minor and major sections. Or that any sin is a great sin by disobeying the Great God. Sheikh Tūsī says:

All sins seem to us to be great because they contain the disobedience of the Great God, but when sins are compared to each other, some may seem greater than others. Ibn 'Abbas says: Whatever God forbids, it is a great sin. Sa'id ibn Jubayr says: What God has threatened to fire is great. Sheikh Tūsī adds: In this verse, it was not permissible for God to specify the minor sins, because 
listing them provokes and encourages people towards them. (Tūsī, nd, v. 3, p. 183) Allameh Tabatabai's view is similar to this. (Tabataba'i, 1417, v. 3, p. 323)

Paradise, the result of good deeds: In this hadith, Imam Bāqir (AS) depicts a comprehensive and beautiful plan for a human being to deserve paradise. Believing in the belief principles such as Imamate is part of the way. In the next section, we must follow Imams (AS). There are several aspects in the practical plan: worship, financial help to people, respecting the rights of individuals and the community. The purpose of true belief is to reinforce the practical dimension. Because belief causes the motivation for action otherwise it will have no benefit. Heart beliefs are valuable when they force us to work.

\section{Accepting the Invitation of the Believer Better than Fasting}

Imam Bāqir (AS) says: if anyone intends to fast, then his brother invited him to eat with him, he should accept his invitation and eat with him and make him happy that instead of one day, this will be regarded ten days fasting for him.

God says: (He that doeth good shall have ten times as much to his credit $^{1}$ ) (An $\square$ âm/160) (Ayyashi, 1380, v. 1, p. 386; Kulayni, 1407, v, 4, p. 150)

In this narrative, Imam Bāqir (AS) adduces the verse 160 of surah An $\square$ ām.

This adduce of Imam Bāqir (AS) is a matching kind, and is based on the fact that accepting the invitation of others makes them happy and making others happy is a good deed. God has promised all good things to be rewarded ten times. So this is a license to break the (Mustahab) fast.

Allameh Majlesi says: In this narrative the word "so break ones fast" is absolute and includes fasting as well as any type of fasting that is permissible to break, although it is a Wājib fast except fasting in the holy month of Ramadan. (Majlesi, 1363, v. 16, p. 368)

This hadith shows the value and importance of human intentions. The soul and basis of human action is formed by his purpose, as verse 84 of surah Isrā $\square$ states:

(Say:" Everyone acts according to his own disposition: But your Lord knows best who it is that is best guided on the Way.) (Isrā $\square / 84$ )

In this hadith, Imam Bāqir (AS) considers no problem to break the fast because he intends to accept the invitation of a believer and make him happy, believing it to be a positive and desirable act in the presence of God, and is rewarded more than the Mustahab fast. 


\section{Public Relations}

Zurarah says: I said to Imam Bāqir (AS): we use balance (to distinguish the believer from the non-believer) whoever agrees with us, we know him a friend of ours, whether he is Alawite or not and anyone opposes us, we hate him. Imam Bāqir (AS) replied: The word of God is better than your word. So where are the oppressed ones, about whom God has said: (Except those who are (really) weak and oppressed including men, women, and children, who have no means in their power, nor can they find a way (to escape) $\left.{ }^{1}\right)$ (Nisā $\left.\square / 98\right)$

Where are those who hope in God?( waiting Allah's edict.) (At-Tawbah/106)

Where are those who have mixed the good and the bad? (those who have confessed to their sins, having mixed up righteous conduct with other that was evil.) (At-Tawbah/102)

Where are the companions of the noble? (The Companions on the Heights will call out) (Al$\mathrm{A} \square \mathrm{rā} / 48)$

Where are those who need to be tolerated in order to attract them? (whose hearts are to be reconciled) (At-Tawbah/60) (Kulayni, 1407, v. 2, pp. 282-283; Ḥwayzī, 1415, v. 1, p. 538)

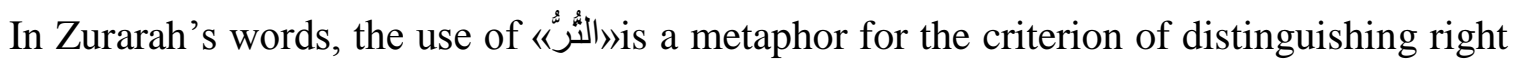
from wrong. Imam Bāqir (AS) citing the verse 98 of surah Nisā $\square$ and allusion to four other verses (Al-Tawbah: 106); (Al-Tawbah: 102) (Al-A $\square$ rāf: 48) (Al-Tawbah: 60) tells Zurarah that you must tolerate people and not be harsh.

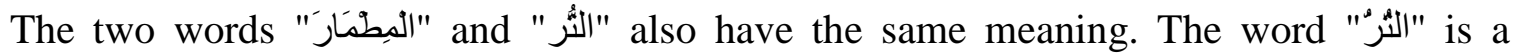
Persian word that has entered the Arabic language. This word means the string or thread with which the building is measured and drawn (Ibn Manẓ ūr, 1414, v. 4, p. 190).

In these narratives, this word has been used for recognizing the right from wrong. (Tureyhī, 1375 , v. 3, p. 233)

Mulla Saleh Mazandarani says:

Zurarah says "whoever agrees us" is a believer who has a firm faith and does not commit a great sin. That is to say, anyone who does not have these three characteristics, we will hate him. But Imam Bāqir (AS) rejects all three attributes by citing the verses. With the verse 98 of surah Nisā $\square$, he removed the unaware unbeliever. That is, an infidel who does not know the truth but does not deny it. By the verse 60 of surah Tawbah, he removed the believers who believe but the faith has not yet established in their hearts because they are close to ignorance and the Prophet (PBUH) gave them zakat and alms to absorb their hearts. And with three other verses he expelled three groups of sinners: the sinners hoping for God's mercy; the doers of good and evil and the companions of the Heights. Zurarah considered all of these groups as the opponents, and Zurarah believed that they should be denied. (Muhammad Hadi ibn Muhammad Saleh Mazandarani, nd, v. 1, p. 35) 
Huwayzī quotes Feyz Kashani: Zurarah means that we have set the balance for Tawallī and Tabarrī to separate the Shiites from the non-Shiites. (Huwayzī, 1415, v. 2, p. 53 footnote)

However, Imam Bāqir (AS) did not accept the balance of Zurarah, and invited him to tolerate and soften the ignorant opposition.

Kindness of Imam Bāqir to ignorant sinners: Zurarah seeks a unified ruler who distinguishes the opposition from the believers and seeks hatred from with opposition. Imam Bāqir (AS) confirms him by citation and allusion to five Qur'anic verses and persuades him to be more flexible and kind.

First: Because some people are at a moderate level. Neither completely good nor bad, perhaps, yet the culture and knowledge of religion have not yet fully reached them.

Secondly, in order to attract the hearts of sinners, we must be gentle to them. So it becomes clear that the evangelist in dealing with the populace cannot evaluate people with an outlined version (or, as Zurarah: Aligns), with the least flaw, making them an enemy of God and the Prophet.

One of the wonders is that most of the verses used in this narrative to attract the affection of Zurarah to the mean and guilty people come from the Surah At-Tawbah. A surah called Disavowal, which is said to have no Basmala at the first of surah because of the wrath of God. So God's wrath is only for the oppressors. Otherwise, all the verses full of mercy in this surah did not make sense!

\section{Reasoning in Relations with Bad People: Agreement in Ethics and Disagreement in Deeds}

Imam Bāqir (AS) said: O, Abu Ubaydah, associate with the people in harmony with their moods, (but) in practice act differently, if man doesn't understand the error of speech, we will not consider him wise, and then he recited this verse: (You can know them by their words) (Muhammad/30) (Ibn Babawayh, 1398, p. 459)

Imam Bāqir (AS) has adduced this verse to be a witness for his word.

The word 'tone' sometimes means spoken error and sometimes 'allusion' and 'reference', meaning that they talk somehow that only the audience understands the speaker's true meaning. This is well-liked by the scholars. (Rāghib Isfahani, 1412, p. 449; Ibn Manz ūr, 1414, v. 13, p. 379). Many interpretations have taken into account these two meanings (Tūsī, nd, v. 9, p. 905; Ṭabarsī, 1372, v. 9, p. 176; Shokani, 1414, v. 5, p. 40; Tabataba'i, 1417, v. 18, P. 243). What Imam Bāqir (AS) means is that in social relations with bad people, one must be wise and discerning, to know the tone of speech and to know how to be present in the community and to associate with the good people and not to do their bad deeds. Sometimes it is necessary for a person to talk to people in accordance with observing the principles of speech (cited in the science of rhetoric meanings), both to communicate well with people and to avoid common lies in society, and if two persons talked ironically in his presence, he should understand with awareness, and know the people. Most importantly, if he associates with bad people, he should never be like them and do their bad deeds. 


\section{Emotional and Brotherly Relationship among Believers}

Imam Bāqir (AS) said: "The believer is the true brother of the believer, and God created the nature of all believers from the seven heavens, namely from the mud of paradise. Then he recited this verse: (Prophet Muhammad and his followers are kind to one another) and said: Shouldn't a person be kind to the believers who are his relatives?" (Barqi, 1371, v. 1, P. 134; Bahrani, nd, v. 5, p. 95)

Imam Bāqir (AS) has adduced this verse: (Mohammad is the Messenger of Allah and his followers are stern and hard against the disbelievers but kind and Compassionate to each other.) (Fatḥ : 29).

In this speech, Imam Bāqir (AS) considered believers to be brothers and belonging to one family, who should be kind to each other like relatives. And prefer the comfort of one another to their comfort. As the early believers of Islam had such a good emotional relationship that God said about them: (They are stubborn and intense against infidels, but they are kind to one another.) they had a warm social encounter with each other and they greeted each other in each meeting.

\section{Start Training with Easy Commands}

Imam Bāqir (AS) said: "When God sent Prophet Muhammad (PBUH), he was in Mecca for ten years... and when the followers of Muhammad (PBUH) died in Mecca, God didn't punish them unless they were polytheists. And this is because Allah revealed surah Isrā $\square$ in Mecca: (And your Lord has commanded: Thy Lord hath decreed that ye worship none but Him, and that ye be kind to parents. Whether one or both of them attain old age in thy life, say not to them a word of contempt, nor repel them, but address them in terms of honor.) (Isrā $\square / 23$ ) That includes mild polite, preaching and teaching and forbidding and forbidding things, but if anyone did it, there would be no threat to him (i.e. The threat to the fire of hell.) (Kulayni, 1407, v. 2, p. 29-30; Huwayzī, 1415, v. 3, p. 160.)

In this narrative, Imam Bāqir (AS) cites the verses 23-30 of surah Isrā $\square$ and has mentioned these verses as a document and reason for his word.

Imam Bāqir (AS) says: In Mecca divine orders were easy and light. In the Meccan verses, the threat of believers is less observed. The followers of Muhammad (PBUH), who were died in Mecca, will not be punished for their evil deeds, and only the confirmation of God and the Prophet will be required.

In other words, anyone who died before the migration, would be punished only for the sin of idolatry, and if he was not idolater, he would not be punished.

The verse (your Lord will judge ${ }^{1}$ ) confirms that God revealed some verses in Mecca that had easy and simple commands, and its tone was not intense and threatening so it has no 
punishment, since punishment must be after the threat and intensity. (Muhammad Hadi ibn Muhammad Saleh Mazandarani, nd, v. 8, p. 93)

There is a point in this narrative that when we want to educate a person or a community and lead him from the wrong way of life toward the right plan, we must first give simple and easy instructions and avoid the threat of violence. That is, we use the gradual method in training.

\section{Manifestation of the Qur'anic Verses in the Ethical Narrative of Imam Bāqir (AS) and the Prohibition of Bad Attributes}

In the following we will mention 5 examples of Imam Baqir's (AS) narratives in which the bad attributes have been forbidden.

\section{Prohibition of Speech and Questions in Vain}

Imam Bāqir (AS) said: "Whenever I speak to you, ask me for a Qur'anic reason, then he said: Allah has forbidden speech in vain, wasting wealth and too much questions. (Audience) asked: O, son of Prophet, where does this story come from? He said: The Almighty God has said in His book: (In most of their secret talks there is no good: But if one exhorts to a deed of charity or goodness or conciliation between people, (secrecy is permissible) ${ }^{1}$ ) $(\mathrm{Nis} \bar{a} \square / 114)$ and said (To those weak of understanding give not your property which Allah has assigned to you to manage ${ }^{2}$ ) (Nisā $\square / 5$ ) and said (Ask not questions about things which, if made plain to you, may cause you trouble $\left.^{3}\right)($ Al-Mā $\square$ idah/101) (Barqi, 1371, v. 1, p. 269; Kulayni, 1407, v. 1, p. 60; Huwayzī, 1415 , v. 1, p. 443)

Imam Bāqir (AS) forbids the three ugly things by adducing three verses of the Qur'an: speech in vain, wasting of property, pointless questions. Speech in vain: "God has forbidden speech in vain": That means no further talk is allowed. Such as following people's news and their work and speech or useless events that not only teach no wisdom but also cause the heart to lose its chance to acquire religious sciences (Muhammad Hadi ibn Muhammad Saleh Mazandarani, nd, v. 3, P. 281) Imam Bāqir (AS) adduces the verse 114 of surah Nisā $\square$ to confirm his statement.

Useless Spending of Property: Avoid "corruption of money", which means destruction of property. Like spending property in illegal ways, not maintaining it, paying off debts without witnessing and lending money to a traitor. Imam Bāqir (AS) has adduced the verse 5 of surah Nisā $\square$ to confirm the phrase.

Pointless question: "too much questions" means many questions about things that have no worldly or the Hereafter benefit (Muhammad Hadi ibn Muhammad Saleh Mazandarani, nd, v. 3, p. 282) Imam Bāqir (AS) adduces the verse 101 of surah Mā $\square$ idah to confirm this statement. 
Some people are used to asking a lot of questions, or researching about others' lives and secrets. In Islam, vain questions have been blamed.

\section{Prohibiting the stinginess by constantly reminding to oneself}

Abu Basir says: I asked Imam Bāqir (AS): "Does the Prophet of Allah seek refuge in Allah from stinginess? He replied: Yes, Abu Muhammad, I seek refuge in Allah in the morning and in the evening. The Almighty God says: (and those who are secure from the greed of their own souls, [like these Assisters] they have indeed attained Salvation) (Hashr/9) "(Ibn Babawayh, 1385 , v. 2, p. 548; Bahrani, nd, v. 5, p. 162; Huwayzī, 1415, v. 2, p. 382)

In this narrative, Imam Bāqir (AS) adduced the verse 9 of surah Hashr to affirm his statement.

Parsimony ${ }^{1}$ is more severe than stinginess and it means stinginess with greed. Because stinginess is in material things, but Parsimony is both in material and things and in goodness, that is, the spirit of man is greedy toward the forbidden, and this trait has penetrated him. (Rāghib Isfahani, 1412, p. 256; Tureyhī, 1375, v. 2, p. 478).

The commentary states: (يوق: yūq) is the passive present verb derived from the verb (وقاية: wiqāyah) meaning "preserve" and is meant to be preserved by God.

The verse 12 of surah Taghābun (And whoso is saved from his own greed ${ }^{2}$ ) means: The one is prosperous who is preserved by God from greed, so as not to be upset when forgiving his possessions, and not to be disturbed by the possessions of others (such are the successful.) (Tabataba'i, 1417, v. 19, pp. 206-207)

The constant education of oneself to be away from the greed:

The verb (يوق: yūq) has come passive, and regarding the interpretation we see that its subject is God, and He is the one who keeps us from greed and any evil. So Imam Bāqir (AS) draws our attention to seek refuge in God from greed and pray, for example, every morning and evening, and say: (O my beloved I seek refuge from greed) or (I seek refuge in God from parsimony); It is a round-the-clock reminder that reminds man of this bad trait, and when man remembers it, he will exhort himself and change his intrinsic attributes and finally he will be happy.

\section{Preventing the slander and scandal due to its consequences}

Imam Bāqir (AS) said: This verse was revealed in Medina: (And those who launch a charge against chaste women, and produce not four witnesses (to support their allegations), flog them with eighty stripes; and reject their evidence ever after: for such men are wicked transgressors) (Nūr/4-5) Imam Bāqir (AS) said with reference to this verse, that anyone who 
makes such an accusation, is not regarded a believer by God, as He has said in another verse: (Is a believer equal to an evil-doer? They are not equal at all.) (Sajda/18)

And God considers him a hypocrite since He has said in another verse: (The hypocrites indeed are evil-doers.) (At-Tawbah/67) and Allah considered him a friend of Satan and said in another verse: ( Iblīs was a jinn and he sinned against the command of his Lord. Why do you (people) obey him and his offspring instead of Me? (Kahf/50)

And God also cursed the accusers and left them far from the divine mercy: (Those who slander the unaware but chaste and believing women (of committing unlawful carnal relations) are condemned in this life and in the life hereafter. They will suffer a great punishment.) (Nūr/23)

Imam Bāqir (AS) cites five verses of the holy Qur'an (Nūr: 4-5; Sajda: 18; At-Tawbah: 67; Nūr: 23-24; Kahf: 50) to state four negative consequences for accusing the others. Imam Bāqir (AS) first recites verse 4 of Surat Nūr, which is about the sin of accusing the innocent women and shedding their honor. There are three consequences to this sin: One is that the one who accuses someone, must be flogged eighty lashes; the second is that his testimony should never be accepted, because in the verse (Never accept their testimony thereafter ${ }^{1}$ ) the word "testimony" is in a negation state which promotes publicity (Muhammad Saleh ibn Ahmad Mazandarani, 1387, v. 8, p. 97). Third, God has called him an evil-doer, that is, he has fallen out of the obedience to God.

Imam Bāqir (AS) cites verse 4 of surah Nūr to prove the accuser is an evil-doer, and cites verse 18 of surah Sajda to prove such a person is out of the faith circle, and cites verse 67 of surah Tawbah to prove he is a hypocrite. Because this part of verse restricts the evil in hypocrisy and this restriction is the reason why every evil-doer is a hypocrite (Muhammad Saleh bin Ahmad Mazandarani, 1387, v. 8, p. 97) and cites verse 50 of surah Kahf to introduce the accuser as a friend of Satan (Iblīs) and cites verse 23 of surah Nūr to introduce him as a cursed person and far from divine mercy. Of course, if he repents and says to the people: I lied, that is, he denies the accusation from the pure woman, he would return to the faith and be called a believer again, because Imam Bāqir (AS) says:

"Until he insists on his accusation."

\section{Prohibiting the Illegal Relationships}

In the hadith: "Abu Basir asked Imam Bāqir (AS): Did all the people of the city of Prophet $L \bar{u} t$ performed the sin of homosexuality? He said: Yes, except the people of one house who were believers, have you not heard this verse? Then we brought forth such believers as were there. But We found there but one house of those surrendered (to Allah). (Dhāriyāt /35-36) (Ayyashi, 1380, v. 2, p. 245; Ibn Babawayh, 1385, v. 2, p. 548; H. uwayzī, 1415, v. 2, p. 382) 
Imam Bāqir (AS) confirms his speech by adducing these two successive verses: (Dhāriyāt /3536)

Lüt is a special name, and the name of a Prophet who was a relative of Prophet Abraham (PBUH). On the meaning of the word Lüt , scholars have said: The infinitive of Lüt means to insist, (Farāhīdī, 1409, v. 7, p. 451), to cling (Ibn Fāris, 1404, v. 5, p. 221), and to be desirable, and the illegal act of people of Lūt is called "Lawāt : sodomy" because of the fact that the name of the act was derived from the name of its forbidder rather than the name of its doers. (Rāghib Isfahani, 1412, p. 456). )

Prophet Lüt (PBUH) is the nephew of Prophet Abraham (PBUH). (Tureyhī, 1375, v. 4, p. 272; Tabataba'i, 1417, v. 7, p. 219)

God sent Lūṭ for the people of "Sadūm". They were idolatrous, and Prophet Lüṭ (PBUH) invites them to monotheism. (Tabataba'i, 1417, v. 8, p. 183) They committed a type of prostitution (i.e., homosexuality) that was unprecedented. When public destruction was predestined for them, there was only one faithful family in Sadūm, which was the house of Prophet Lüt . Except his wife who was not a believer (Tabataba'i, 1417, v. 7, p. 246).

Imam Bāqir (AS) answers Abu Basir's question with a Qur'anic adduce. The meaning of the verse (except one house of Muslims ${ }^{1}$ ) is that there were only one house or family in the city who were believers and did not perform the heinous act of homosexuality. It was the house of Lüt .

\section{Prohibiting the Short-Change due to its Ugliness}

Imam Bāqir (AS) said: "God revealed this verse about bushel: (Woe unto the defrauders) (Mut affifin /1) and whenever God uses Woe for someone, called him disbeliever and the almighty God has said: (but woe unto the disbelievers from the meeting of an awful Day) (Maryam/37) (Kulayni, 1407, v. 2, p. 32; H. uwayzī, 1415, v. 3, p. 337)

Imam Bāqir (AS) cites these two verses to prove the short-changers are the same disbelievers.

Mutaffifin means those who short-change in balance and in the right of the people. (T abarsī, 1372, v. 10, p. 291)

But there are two quotes about the concept of the word "woe" that has been mentioned 18 times in the Qur'an:

First quote: Woe is a valley in hell that melts the mountains from its heat. (Tureyhī, 1372, p. 485) And the pus and blood of the people of the hell are flowing there. (Tūsī, nd, v. 9, p. 250)

Second quote: Woe is the severe destruction and torment, sorrow, scandal, humiliation, and everything, from which man avoids (Tabataba'i, 1417, v. 1, p. 215). 
Allameh Majlesi says: Imam Bāqir (AS) argued that "Woe" in the Qur'an is only for the disbelievers, such as:

(and woe unto the disbelievers from an awful doom $\left.{ }^{1}\right)($ Abraham / 2)

(Woe unto them for that their hands have written, and woe unto them for that they earn thereby ${ }^{2}$.) (Baqarah/79)

(Then woe unto those who do wrong from the doom of a painful day ${ }^{3}$ ) $($ Zukhruf $/ 65)$

(Woe to us! Who has raised us up from our graves $?^{4}$ ) (Yā Sīn/ 52)

(Woe to us! We have been indeed, rebellious ${ }^{5}$ ) (Qalam/31) (Majlisī, 1363, v. 7, p. 195)

\section{Conclusion}

In this study, 14 narratives of Imam Muhammad Bāqir (AS) have been studied in the field of ethical issues, about which 30 Qur'anic verses have been manifested. Since the 14 infallible Imams are exemplary for us, and their speech is our pattern, we can learn from them how and for what purpose we use the verses of the Qur'an in our speech. Imam Bāqir (AS) sometimes teaches the method of interpretation of the Qur'an with the Qur'an, and with the logical alignment of several verses together, reaches a rational and logical conclusion and in fact makes the verses of the Qur'an a document and reason for his speech. Sometimes he wants to explain to us that the Holy Qur'an is our scientific and religious reference, and has a special place, and has priority over other texts and sources. Sometimes Imam Bāqir (AS) wants to explain to us his position and the position of other Imams (AS). Sometimes he takes us through the Qur'an to teach us the Qur'anic verses have deep and wonderful concepts and we should not simply pass by them. Sometimes he actually teaches us what points we should refer when we want to repel the enemies and what principles we should observe in such situations. Sometimes he speaks with an allusion to the verses.

This variety of ways of relating the speech to Qur'an, and the various ways of using the Qur'anic verses, indicate that the Qur'anic word and logic are imbedded in the soul of Imams, and the scientific and epistemic status of Imam Bāqir (AS) toward Qur'an is to some extent that the Imam himself is a talking Qur'an and is an interpreter and commentator of the Quran. All of the 14 infallible Imams have this religious authority and position. This article presents some of the narratives of the fifth Imam of the Shiite, Imam Muhammad Bāqir (AS), who has explained the moral virtues by adopting the Qur'an and its verses. Ethical virtues such as flexibility in the acceptance of the right is the dignity of believers, public relations, rationality in public relations, 
avoidance of vain word, avoiding asking too many questions from people, avoiding stinginess and accusing the people, avoiding illicit relationships, etc.

\section{References}

- Ayyashi, Muhammad ibn Mas'ud (1380), Tafsir al-Ayyashi, Tehran: Islamic Scientific School.

- Bahrani, Hashem Ibn Suleiman (nd), al-Burhān Fi Tafsir al-Qur'an, Qom: Bi $\square$ tha Institute, Department of Islamic Studies.

- Barqi, Ahmad ibn Muhammad (1371), al-Mahāsin, Qom: Dar al-Kutub al-Islamī.

- Dad, Sima (1371), Dictionary of Literary Idioms, Tehran: Morvarid Publications.

- Farāhīdī, Khalil ibn Ahmad (1409), Al-Ain Book, Second Edition, Qom: Hijra Publishing.

- Feyz Kashani, Muhammad ibn Shah Murtiza (nd), Tafsir al-Safi, Tehran: Maktabah alSadr.

- Huwayzī, Abd Ali ibn Jumu'ah (1415), Tafsir Noor al-Thaqalayn, Qom - Iran: The Ismaili.

- Ibn Babawayh, Muhammad ibn Ali (1362), al-Khisāl, Qom: The Teachers' Society.

- Ibn Babawayh, Muhammad ibn Ali (1385), $\square$ Ilal al-sharāyi $\square$, Qom: School of AlDāwari.

- Ibn Babawayh, Muhammad ibn Ali (1398), Tawhid, Qom: The Teachers' Society in the scientific estate of Qom, Islamic Publication Institute.

- Ibn Duraid, Muhammed ibn Hasan (nd). Jamhara 'l-Lughat, Beirut: Dar al-Ilam Lil Malayin.

- Ibn Fāris, Ahmad ibn Fāris (1404), Mu $\square$ jam Maqayes al- Lughat, Qom: Islamic Information Office Publishing Center.

- Ibn Jawzi, Abd al-Rahman ibn Ali (1422), Zad al-Masir fi Ilm al-Tafsir, Beirut: Arabic Book House.

- Ibn Manẓ ūr, Muhammad ibn Makram (1414), Lisān al-Arab, Third Edition, Beirut: Dar Al-Fikr for Printing, Publishing and Distributing, Dar Sādir.

- Jawādī Âmulī, Abdullah (1377), Thematic Interpretation of the Holy Qur'an (Quranic Ethics), Qom: Isrā̄ $\square$ Publishing.

- Khoei, Sayyid Abu al-Qasim (nd), al-Bayān fi Tafsir al-Qur'an, Qom: Institute for the Restoration of the Works of Imam Khoei.

- Kulayni, Muhammad ibn Ya'qub (1407), Al-Kafi, Fourth Edition, Tehran: Dar al-Kutub al-Islami.

- Majlisī, Muhammad Bāqir ibn Muhammad Taqi (1363), Mira't al-Uqūl fi Sharh Ikhbar Âl Rasūl, Tehran: Dar al-Kutub al-Islam.

- Mazandarani, Muhammad Hadi ibn Muhammed Saleh (nd). Sharh Furu' Kafi (Mulā Muhammad Hadi ibn Muhammad Saleh al-Mazandarani), Qom: Dar al-Hadith Scientific and Cultural Institute, Publishing Organization.

- Mazandarani, Muhammad Saleh ibn Ahmad (1387), Sharh Usūl Kafi wa al-Ruzih, Tehran - Iran: The Islamic School of Publishing and Distributing.

- Motahhari, Morteza, (1389), Introduction to Islamic Sciences, Tehran: Sadra. 
- Qurt ubī, Muhammad ibn Ahmad (1363), al-Jami' li Ahkām al-Qur'an, First Edition, Tehran: Nāser Khusru.

- Rāghib Isfahani, Hussein ibn Muhammed (1412), Al-Mufradat fi Gharib al-Qur'an, edited by Safwan Adnan Davoodi, first edition, Beirut: Dar al-Ilam Dar al-Shamiyah.

- Ray Shahri, Muhammad (nd), Mizan al-Hikmah, Qom: Dar al-Hadith.

- Shokani, Muhammed (1414), Fath al-Qadir, first edition, Damascus/Beirut: Dar Ibn Kathīr, Dar al-Kalam al-Tayyib.

- Suyūt $\overline{1}$, Jalal al-Din (1404), al-Dur al-Mansour fi Tafsir bil-Ma'thur, Qom: Public Library of Ayatollah Mar'ashi Najafi.

- T abarī, Muhammed ibn Jarīr (1412), Jami' al-Bayan fi Tafsir al-Qur'an, first edition, Beirut: Dar al-Ma'rifah.

- Ṭabarsī, Fazl ibn Hasan (1372), Majma al-Bayan fi Tafsir al-Qur'an, Third Edition, Tehran: Nāser Khusru.

- Tabataba'i, Muhammad Hossein (1417), al-Mizan Fi Tafsir al-Qur'an, Qom: Islamic Publications Office of the Qom Seminary Teachers.

- Taftazani, Sa'ad al-Din (1411), Mukhtasar al-Ma'anī, Qom: Dar al-Fikr.

- Tha'labī, Abdul Rahman ibn Muhammed (nd), Tafsir al-Tha'labī al-Musamma bilJawahir al-Hisan fi Tafsir al-Qur'an, Beirut: Dar Îhyā al-Turāth al-Arabī.

- Ṭ urayh $\overline{1}$, Fakhr al-Din ibn Muhammad (1375), Majma' al-bahrayn, Tehran: Mortazavi.

- Ṭuraỵ̣ $\overline{1}$, Fakhr al-Din bin Muhammad (1372), Tafsir al-Qarib al-Qur'an al-Karim, Najaf: Matba' al-Haydariyyah.

- Tūsī, Muhammed ibn Hasan (nd), al-Tibyān fi Tafsir al-Qur'an, first edition, Beirut: Dar Īhyā al-Turāth al-Arabī. 